\title{
PENGEMBANGAN PASAR DAN KUALITAS DESAIN TERHADAP SENTRA ROTAN DI PADANG
}

\author{
Kendall Malik \\ Rahmad Washinton \\ Rusnal Firdaus
}

\begin{abstract}
Program Studi Desain Komunikasi Visual, Fakultas Seni Rupa dan Desain, Institut Seni Indonesia Padangpanjang Jalan Bahder Johan Padangpanjang 27128. Padangpanjang Sumatera Barat kendallmalik1981@gmail.com
\end{abstract}

\begin{abstract}
ABSTRAK
Rotan disebut bahan sejenis bambu yang dapat digunakan ke berbagai macam bendabenda kerajinan. Benda-benda yang menggunakan bahan rotan seperti keranjang, kap lampu dan furnituree-furnituree. Ini dapat dibuktikan melalui banyaknya kios-kios dan sentra kerajinan rotan yang terdapat di Indonesia, terlihat dari masa lalu sampai masa sekarang dimana masih digemari oleh masyarakat di Indonesia. Perkembangan kerajinan rotan telah menjamur di daerah-daerah di Indonesia khususnya produk furnituree rotan. Hal ini menjadi suatu peluang pasar bagi pengrajin-pengrajin furnituree rotan terhadap konsumen sekarang. Di Sumatera Barat khususnya Kota Padang, furnituree rotan telah memiliki distributor dan target konsumennya di Kota Padang. Pengembangan produk furnituree rotan perlu dikembangkan karena potensi pertumbuhan bahan rotan ini sangat pesat namun pada furniture rotan yang merosot. Hal ini menjadi penting utuk mengadakan kegiatan pengabdian kepada masyarakat di sentra rotan di Padang yaitu Toko Furnituree Anil yang berlokasi di By Pass, Padang. Sesuai dengan tujuan dan target serta mitra dari pelaksanaan pelatihan perlu ditetapkan metode pelaksanaannya. dengan metode diskusi, demonstrasi dan praktek.
\end{abstract}

Kata Kunci: Rotan; Strategi; Desain; Furnituree Anil.

\section{PENDAHULUAN}

Rotan merupakan tumbuhan yang tumbuh di hutan-hutan rimba yang beriklim tropis. Kebanyakan hutan tempat rotan-rotan tumbuh dengan baik biasanya tumbuh di daerah yang teduh dan lembab. Daerah-daerah di Indonesia tidak semua menghasilkan rotan, namun ada beberapa kepulauan di Indonesia yang menghasilkan rotan, meliputi: Kepulauan Kalimantan, Sulawesi, Sumatera, sebagian kecil 
pulau Jawa, dan beberapa kepulauan lainnya. (Prabu Wardono, 2009 : 65). Rotan disebut bahan sejenis bambu yang dapat digunakan ke berbagai macam benda-benda kerajinan. Bendabenda yang menggunakan bahan rotan seperti keranjang, kap lampu dan furnituree-furnituree. Ini dapat dibuktikan melalui banyaknya kios-kios dan sentra kerajinan rotan yang terdapat di Indonesia, terlihat dari masa lalu sampai masa sekarang dimana masih digemari oleh masyarakat di Indonesia.

Perkembangan kerajinan rotan telah menjamur di daerah-daerah di Indonesia khususnya produk furnituree rotan. Hal ini menjadi suatu peluang pasar bagi pengrajin-pengrajin furnituree rotan terhadap konsumen sekarang. Di Sumatera Barat khususnya Kota Padang, furnituree rotan telah memiliki distributor dan target konsumennya di Kota Padang. Kota Padang telah memiliki sentra-sentra kerajinan rotan yaitu By Pass, Tanah Sirah dan Palapa. Hal ini menjadi perhatian khusus bagi penulis untuk diteliti perkembangan desainnya. Pada pengabdian Kepada Masyarakat ini penulis memfokuskan pada sentra Hal| 2 kerajinan furnituree rotan di By Pass yaitu Toko Anil Furnituree, By Pass Padang.

Keberadaan Toko Anil furnituree sudah berdiri dari tahun 1991. Toko Anil memiliki 3 (tiga) buah toko yang terdiri dari 2 (dua) buah toko berlokasi di Kota Padang (By Pass) dan 1 (satu) buah berlokasi di Kota Payakumbuh. Toko Anil furnituree merupakan distributor furnituree rotan di kota Padang. Menurut Bapak Agus selaku pengrajin dan pengelola Toko Anil menyatakan "Perkembangan furnituree di Padang cukup pesat dan yang banyak diminati yaitu furnituree rotan bergaya gentong (bulat-bulat seperti tabung) namun beda dengan di pulau Jawa yang diminati bergaya minimalis".(Wawancara dengan Bapak Agus, pada tanggal 06 Maret 2019, pada pukul 10.00 s.d 11.00, di Padang). Hal ini menjadi bukti bahwa pasar furnituree rotan di Padang 


\section{Jurnal Batoboh, Vol 6, No1, Maret 2021}

Kendall Malik, Rahmad Washinton, Rusnal Firdaus

menjadi tren untuk interior-interior rumah tinggal di Padang.

Perkembangan furnituree rotan di Padang terlihat begitu-begitu saja dan tidak pernah berubah-ubah. Hal ini pengrajin menjadi latah dengan modelmodel furnituree yang sudah ada atau pengulangan-pengulangan dari bentuk, warna, dan desainnya yang telah dibuat oleh orang sebelumnya. Dan akibatnya furnituree rotan mengalami penurunan dari segi omset dan penjualan dalam waktu 10 tahun terakhir ini. Hal ini dibenarkan oleh Bapak Agus bahwa beliau menyatakan "Furnituree rotan mengalami penurunan dalam waktu 10 tahun terakhir ini mulai dalam omset dan penjualan. Biasanya saya membeli bahan rotan sampai dengan $500 \mathrm{~kg}$ namun sekarang saya mampu membeli $50 \mathrm{~kg}$ disamping itu soal pengrajin yang membuat furnituree mengalami penurunan yang dulu berkerja 15 orang pengrajin sekarang hanya 5 orang pengrajin". (Wawancara dengan Bapak Agus, tanggal 15 Februari 2019, pada pukul 14.00 s.d 16.00, di Padang).
Dengan permasalahan menurunnya perkembangan furnituree rotan ini maka furnituree di Padang tidak meningkat dengan baik.

Permasalahan menurunnya furnituree rotan di kota Padang beberapa tahun terakhir maka perlu sebuah strategi desain dan pengembangan desain produk rotan yang bertujuan untuk meningkatkan pemasukan (income) para pengrajin dan pengusaha di bidang furnituree rotan, dengan ini perlu melalui penyuluhan dalam bentuk kegiatan Pengabdian Kepada Masyarakat diharapkan akan membentuk, menciptakan dan meningkatkan kualitas produk (segi desain), pemasaran (selera pasar) dan pemasukan bagi pengrajin dan pengusaha furnituree rotan sehingga dapat terciptanya nilai jual dan peningkatan produk tersebut.

\section{PEMBAHASAN}

Penyelenggaraan kegiatan pengabdian ini tentunya tidak terlepas dari koordinasi yang dilakukan oleh tim 
pelaksana pengabdian dari ISI Padangpanjang, langkah program yang dirancang oleh tim pengabdi adalah: 1) koordinasi dengan anggota TIM dan Pemilik UMKM 2) Penyuluhan 3) Pelatihan. Tahap awal yang tim laksanakan dalam kegiatan pelatihan ini adalah melakukan koordinasi dengan tim pengabdian. Berkaitan dengan halhal yang perlu dipersiapkan dimulai dari bahan dan alat yang diperlukan pada waktu pelatihan.

Berdasarkan permasalahan yang dihadapi oleh perajin rotan di Sentra Rotan ANIL Furnituree Padang selaku mitra maka tim pengabdian akan melakukan pengembangan desain produk dan strategi desain yang lebih kreatif dan inovatif. Untuk meningkatkan kemampuan perajin mebel rotan dalam menghasilkan desain furnituree rotan dan produk yang kreatif dan inovative.

Adapun alur pelaksanaan kegiatan pengabdian yang tim lakukan adalah :
1. Koordinasi antara Ketua dan Anggota Tim (lihat Gambar 1).

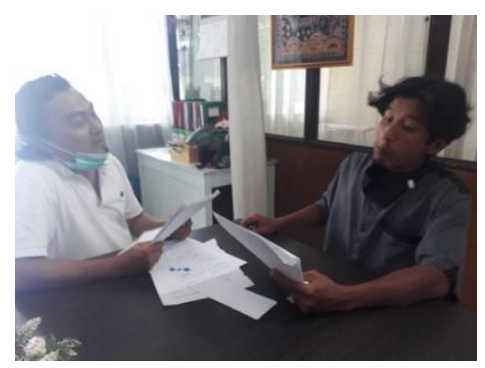

Hal 4

Korndinasi dengan Ketua dan Anggota Tim.

(Foto; Dokumentasi Rusnal Firdaus,2020)

2. Koordinasi dengan Pemilik dan Pengrajin di ANIL Furniture.

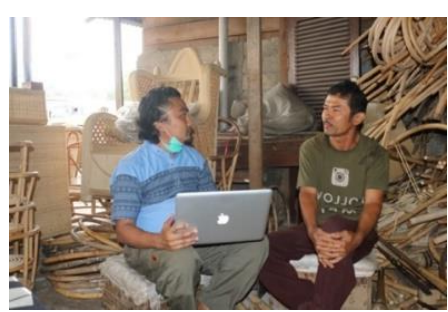

Gambar 2.

Koordinasi dengan Pemilik dan Pengrajin di ANIL Furniture.

(Foto; Dokumentasi Rusnal Firdaus,2020)

\section{Penyuluhan dan Sosialisasi}

Penyuluhan dilakukan kepada perajin mengenai peningkatan kualitas desain furniture rotan melalui pengembangan desain produk dan strategi desain, pengembangan produk dan pemasaran online dari kerajinan 


\section{Jurnal Batoboh, Vol 6, No1, Maret 2021}

Kendall Malik, Rahmad Washinton, Rusnal Firdaus

mebel rotan. Karena dengan dilakukan pengembangan desain yang berkualitas bisa meningkatkan nilai jual dari produk mebel rotan yang dihasilkan di Sentra Rotan ANIL Furnituree Padang. Pada pelaksanaan ini penulis dan tim pengabdian tidak bisa melaksanakan penyuluhan disebabkan pemilik dan pengrajin mendapatkan pesenan kursi rotan dan produk rotan dari konsumen. Hal ini menghambat tim pengabdian pada saat melaksanakan penyuluhan. Namun penulis harus melaksanakan sosialisasi dan penyuluhan secara pribadi atau personal dengan pemilik dan pengrajin. (Lihat Gambar 3.)

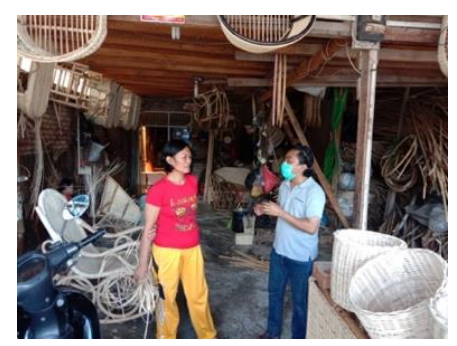

Gambar 3.

Melaksanakan sosialisasi dan penyuluhan (Foto; Dokumentasi Rusnal Firdaus,2020)

Tahap ini penjelasan mengenai pengembangan desain dan strategi desain yang harus dilakukan oleh

pengrajin rotan di Furniture ANIL Hal ini memberikan ide/gagasan segar dimana ide/gagasan tersebut disesuaikan dengan perkembangan Hal| 5 pasar dan kebutuhan pasar sekarang. Untuk itu pasar produk rotan Furniture ANIL harus mengikuti zaman dan tututan perkembangan selera sekarang. (Lihat Gambar 4).

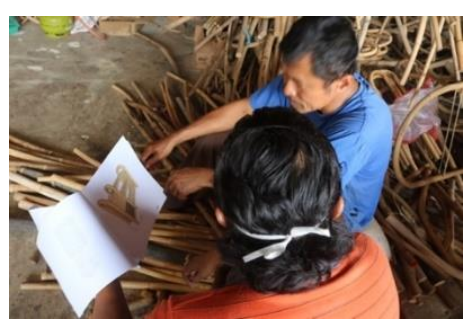

Gambar 4.

Menjelaskan alternatif desain di ANIL Furnituree Padang.

(Foto; Dokumentasi Rusnal Firdaus,2020)

\section{Jenis Anyaman Rotan di ANIL}

\section{Furnituree}

Anyaman pada Gambar 14 merupakan jenis-jenis anyaman yang diaplikasikan pada furniture-furniture dan produk-produk oleh furniture ANIL di Padang. Anyaman - anyaman rotan di atas juga sudah digunakan dari awal berdirinya usaha produk furniture ANIL di Padang. Hal ini sudah menjadi 


\section{Jurnal Batoboh, Vol 6, No1, Maret 2021}

Kendall Malik, Rahmad Washinton, Rusnal Firdaus

cirikhas pada produk baik produkproduk terdahulu maupun produkproduk sekarang. (Lihat Gambar 5).
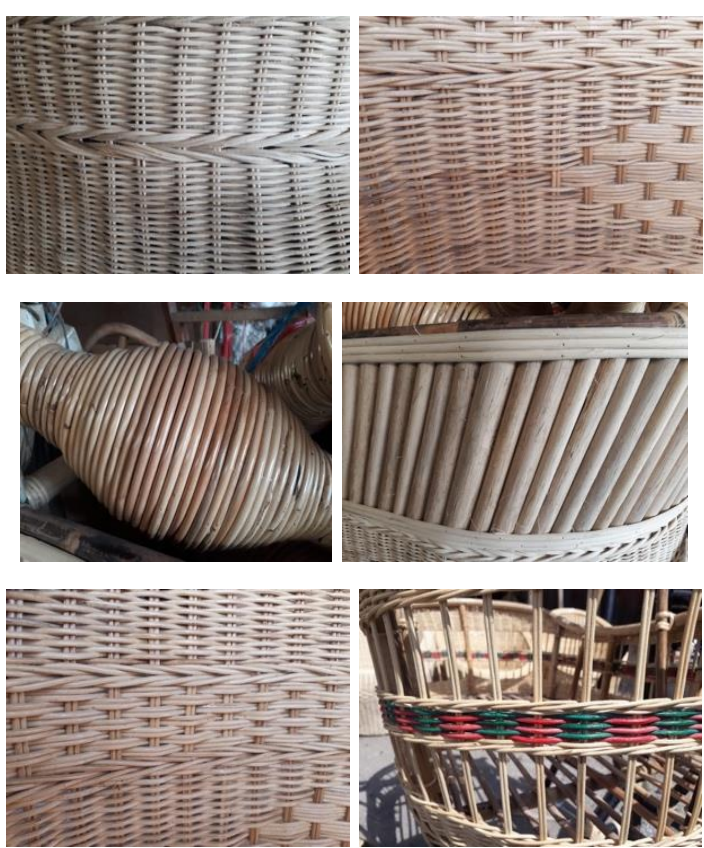

Gambar 5.

Jenis Anyaman di ANIL Furniture

(Foto; Dokumentasi Rusnal Firdaus,2020)

\section{Tahap Pengembangan Desain}

Tahap ini diawali dengan membuat alternatif-alternatif desain yang sudah digitalkan. Pengembangan produk rotan yang diaplikasikan meliputi lampu tidur dan lampu duduk. Tujuan alternatif desain ini memudahkan pengrajin dalam memahami gambar dan memberikan imajinasi ide baru terhadap pengrajin. Pengrajin tidak terbiasa dengan membuat sketsa tapi mereka lebih melihat gambar atau foto yang dibawa oleh klien. (Lihat Gambar 6).
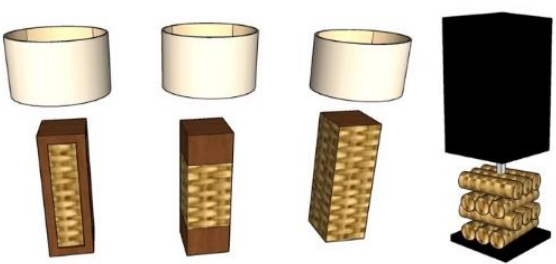

Hal| 6
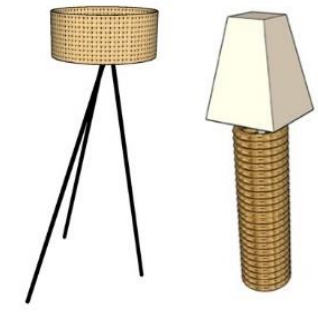

Gambar 6.

Alternatif Pengembangan Desain

(Desain oleh : Kendall Malik, 2020)

\section{Proses Produksi (Prototype)}

Proses produksi yang dibuat oleh pengrajin Furniture ANIL dari hasil alternatif-alternatif desain yang sudah dirancang. Pada pelaksanaan produksi pengrajin Furniture ANIL membagi tiga tugas yang masing-masingnya memiliki keahlian masing-masing seperti pengrajin satu bagian menekukkan rotan dan membuat rangka, kemudian pengrajin kedua bertugas menganyam dan finishing, dan membakar untuk membuang bulu-bulu dan serbukserbuk dipermukaan rotan serta bagian memfernis pada permukaan rotan. 
Dalam proses produksi pada Pengebdian Kepada Masyarakat ini dibagi dengan tiga tahap karena menggunakan material produk yang
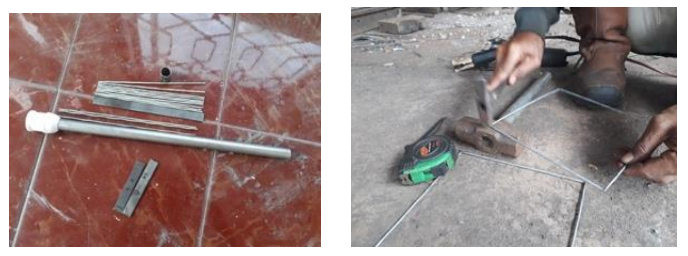

berbeda-beda, yakni (1) Tahap pembuatan produk menggunakan material Rotan, (2) Tahap membuat rangka dengan besi dan (3) Tahap mencat dan pemasangan kain.

(Lihat Gambar 7, Gambar 8 dan Gambar

9). Meliputi :

1. Tahap Pembuatan Produk Rotan

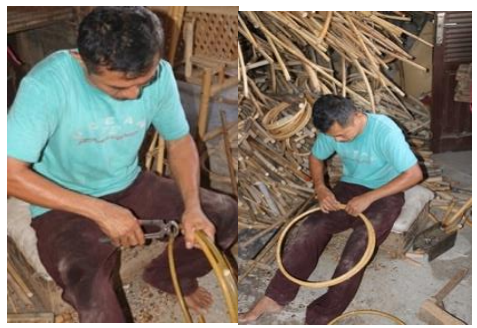

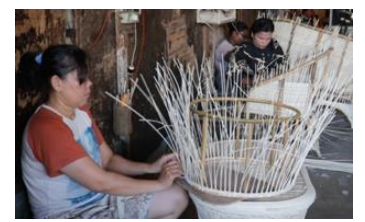

Gambar 7.

Tahap pembuatan produk menggunakan material rotan

(Foto; Dokumentasi Rusnal Firdaus,2020)

2. Tahap membuat rangka besi
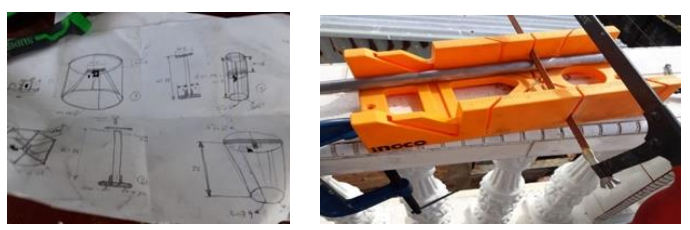

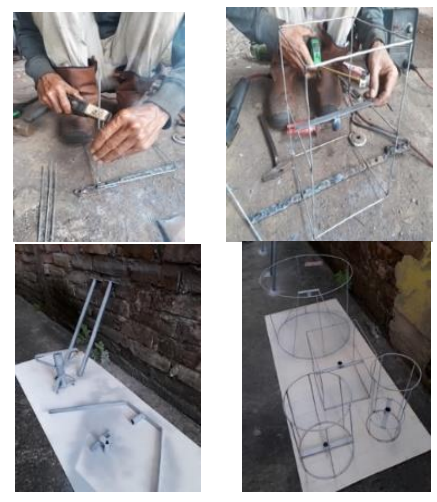

Gambar 7.

Tahap Pembuatan Rangka Besi

(Foto; Dokumentasi,

Rahmad Washinton, 2020)

3. Tahap Pemasangan Kain dan Cat
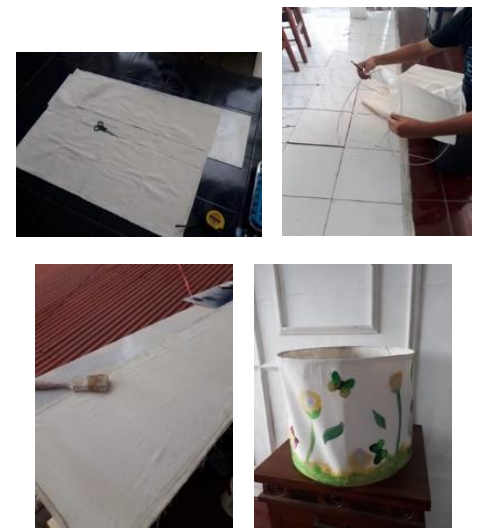

Gambar 8.

Tahap Pemasangan Kain dan Cat

(Foto; Dokumentasi,

Rahmad Washinton, 2020)

\section{Final Desain dan Prototype}

Final Desain atau Prototype merupakan hasil akhir dari proses desain dan tahap yang sudah dilalui dan menghasilkan produk dalam bentuk 


\section{Jurnal Batoboh, Vol 6, No1, Maret 2021}

Kendall Malik, Rahmad Washinton, Rusnal Firdaus

tiga dimensi dan sudah bisa dioperasikan. (Lihat Gambar 9).
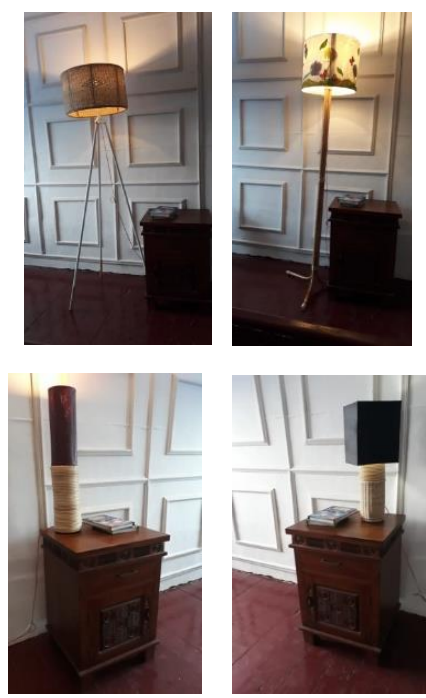

Gambar 9.

Final Desain dan Prototype yang Diaplikasikan (Foto; Dokumentasi, Rahmad Washinton, 2020)

\section{SIMPULAN}

Kegiatan PKM yang berjudul “ PKM

Kelompok Kerajinan Rotan dalam Meningkatkan Kualitas Desain melalui Strategi Desain untuk Mendukung Industri Kreatif di Padang " telah dijalankan, namun dapat disimpulkan bahwa :

1. PKM ini telah memberikan pengalaman antara tim pengabdian dan pengrajin yang ada Furniture ANIL. Pengalaman dalam memahami proses pembuatan furniture rotan sampai dengan hasil menjadi produk (prototype) yang berfungsi dan berguna.

2. Pengrajin tidak terbiasa dengan Hall 8 memberikan pengertian atau penjelasan desain namun pengrajin hanya terbiasa dengan desain yang sudah jadi didesain oleh tim pengabdian dengan hasil print out (cetak) gambar/image dengan tujuan memudahkan pengrajin dalam pengerjaannya.

3. Para pengrajin rata-rata adalah ibuibu rumah tangga yang terdiri 5 orang dan pemilik 1 orang yang berjenis kelamin laki-laki. Hal ini memberi dampak yang positif bagi pemilik sentra rotan dikarenakan pengrajin ibu-ibu rumah tangga tersebut memiliki sifat kerja yang tekun, telaten, dan rapi.

4. Kegiatan PKM yang tim lakukan telah sampai pada pembuatan desaindesain produk rotan yang baru dan telah mengaplikasikannya ke prototype. Desain-desain itu terdiri dari produk - produk penunjang 
interior seperti kap lampu berdiri dan duduk. Alternatif-alternatif desain yang lainnya ini sudah banyak di desain oleh tim pengabdian namun yang terealisasi hanya produk kap lampu.

5. Pengembangan produk penunjang interior untuk PKM ini sendiri tim PKM memberikan solusi desain dengan menggunakan 3 (tiga) jeni material yakni : rotan, besi dan kain kanvas/blacu. Hal ini bertujuan untuk menambah nilai estetika (keindahan), nilai jual dan nilai tambah dalam menangkap selera pasar. Kemudian tim PKM juga mendesain ulang logo Furniture ANIL supaya identitas baru tersebut dapat mengikuti zaman pada saat sekarang ini.

\section{KEPUSTAKAAN}

Joedawinata, A, (2008), Unsur-unsur Pemandu dalam Artefak Tradisional (Artefak Peralatan Anyaman di Kawasan Cirebon,
Bandung, Jurnal Ilmu Desain Institut Teknologi Bandung. Ranjan .M.P, Iyer.N dan Pandya. G, (1986), Bamboo and Cane Crafts of Hal| 9

Northeast India, India, Natinal Institute of Design.

Surianto Rustan, (2009), Desain Logo, Jakarta, Gramedia Pustaka Utama. Vihma, S, (1995), Product As Representations, Helsinki, UIAH. Wolchonok, L, (1953), Design for Artists and Craftmen, New York, Dover Publications, Inc.

Wawancara dengan Bapak Agus, pada tanggal 06 Maret 2019, pada pukul 10.00 s.d 11.00, di Padang) Wawancara dengan Bapak Agus, pada tanggal 05 September 2020, pada pukul 08.00 s.d 09.00, di Padang) Wawancara dengan Bapak Agus, pada tanggal 12 September 2020, pada pukul 09.00 s.d 10.00, di Padang) Wawancara dengan Bapak Agus, pada tanggal 26 September 2020, pada pukul 16.00 s.d 17.00, di Padang) 
Jurnal Batoboh, Vol 6, No1, Maret 2021

Kendall Malik, Rahmad Washinton, Rusnal Firdaus

Hal| 10

Copyright (C) 2021, Jurnal Batoboh, ISSN 2548-5458 (print), ISSN 2599-1906 (online) 